\title{
Navigating the Rural Terrain: Educators' Visions to Promote Change
}

\author{
Margaret Vaughn \\ University of Idaho \\ Melissa Saul \\ University of Hawaii - West Oahu
}

\begin{abstract}
Advocates of rural education emphasize the need to examine supports which may promote rural educators given the challenging contexts of which they face. Teacher visioning has been conceptualized as a navigational tool to help sustain and promote teachers given high-challenging contexts. The current study explored 10 public school teachers from rural areas in the Pacific Northwest, and their visions and challenges to practicing their visions in their respective school environments. Findings suggest that visions were described in three domains: visions of students, visions of self as teacher, and visions of school. Teachers expressed visions of self as 'change agents, 'and often expressed a sense of responsibility and vulnerability as they worked to weave knowledge of effective pedagogy, teacher leadership principles, and self-reflection to implement change in their individual schools.
\end{abstract}

\section{Key Words: teacher visioning, rural education, and agency.}

Rural students comprise $22 \%$ of the nation's public school students, many of whom are faced with issues of poverty and growing high school dropout rates (Johnson \& Strange, 2007). Researchers have found that in addition to these obstacles, rural educators' work is compounded by lack of financial and educational resources; and by limited opportunities for meaningful professional development in their location (Wenger, Dinsmore \& Villagomez, 2012). As a result, teacher retention in rural school districts dwindled (Monk, 2012; National Center for Education Statistics, [NCES], 2010). As the nation faces increased high-stakes assessment pressures and pay for performance measures (See Race to the Top, 2009), the need to understand the visions of in-service rural teachers who choose to remain teaching in their rural contexts is essential.

Advocates of rural education emphasize the importance of refocusing attention and research to understand supports which may promote rural educators (Burton \& Johnson, 2010). Interestingly, scholars contend that teacher visioning has been considered an important tool to help sustain teachers within today's high challenging educational climate (Duffy, 2002; Hammerness, 2008). A vision has been described as a "teacher's conscious sense of self, of one's work, and of one's mission" (Duffy, 2002, p. 334). Consequently, teacher visioning may be a way to provide a pathway for rural educators to grow professionally, given the challenges of teaching in often-times high-poverty, and resource-challenged contexts.

Accordingly, the purpose of this paper is to explore (a) the salient dimensions of rural teachers' visions and the (b) perceived obstacles to practicing their visions. We explore the phenomenon of teacher visioning within rural settings of 10 rural educators, enrolled in a cohort Master's degree program as a way to consider the supports needed to promote rural educators given the post No Child Left Behind era (NCLB, 2001). First, we explored the tensions and difficulties associated with the intersections of one's identity as 'visionary' and 'classroom teacher.' Second, we examine the complex visions that developed over time and suggest the need to explore teacher visioning as a navigational tool, given the challenges of teaching in rural schools today. In doing so, we suggest how current educators, teacher educators, and school administrators might embrace teacher visioning as a means to empower, problem solve, and generate solutions to effective teaching within rural school contexts. For the purposes of this study, a teacher's vision is defined as teachers' selfreported statement of what she/he wishes to become (Duffy, 2002). The following research questions guide the study:

1. What are the salient dimensions of teachers' reported visions across time?

2. What are the challenges to enacting visions within rural contexts?

\section{Theoretical Perspectives}

This study was informed by social constructivism and teacher agency. Social constructivism suggests that learning is socially constructed through participation in local and situated settings (Vygotsky, 1978). In this way, the teachers in the study made meaning of their experiences, visions, roles, and understandings through their 
interactions with one another, through discourse, inclass projects, and the knowledge that developed through their year-long cohort experiences. Accordingly, social constructivism (Tracey \& Morrow, 2012) emphasizes the complex learning that occurs within socially- mediated contexts like that of which was created through the cohort experience. In this way, teachers' reflections, experiences, and interactions within this experience helped to shape their visions. Scholars characterize teacher agency as those actions of which teachers engage to work toward their personal convictions, visions, and beliefs (Paris \& Lung, 2006; Vaughn \& Faircloth, 2011). A cornerstone of agency is the ability of to take action or to enact beliefs despite compelling situations. As such, teachers are active agents who construct their responses to the challenging contexts of which they face, and respond based on their individual visions, beliefs and knowledge domains (Sloan, 2006; Vaughn, 2013). Taken together, social constructivism and teacher agency provide a conceptual framework to examine the current study by illuminating the ways in which teachers developed their visions through the cohort experience and understandings of ways to enact these visions.

\section{Locating Teacher Visioning}

Recent explorations of teacher visioning have provided a context for locating teachers as thoughtful professionals combining their knowledge of effective instruction with their personal convictions, and beliefs (Duffy, 2002; Hammerness, 2006). Visions are shaped in part by classroom situations, and the additional experiences in which individuals engage. Educators who teach according to their visions often take action to meet the individual needs of their students, classrooms, or local school and community despite the challenges they may experience (Vaughn \& Parsons, 2012). Recently, scholars have begun to explore the perspective of rural educators as they work to enact their personal convictions for teaching. For example, Bates (2011) in his study of rural music educators, found the need to develop "visions" that extend beyond the view of rural contexts as 'deficient' sites.' Bates (2011) cautioned against a static, 'deficit oriented' view of rural schools, when his colleagues described their rural location as a "vast musical wasteland" (p. 94). In highlighting these rural educators' views, he described the necessity of possessing a vision of what could be within rural contexts (i.e., the affordances of teaching within rural communities: close connection to the community, and a familiarity with the community given its resources). Moreover, he challenged images that many of his colleagues had of rural contexts, and expressed the need to extend these visions "to think critically-to step back and observe... we can help to develop affective and cognitive skills... and help students see that rurality is diverse" (p. 95).

Similarly, the educators in this study viewed their rural schools as complex sites full of potential and exploration.

Goodpastor et al. (2012) highlighted the beliefs and intersections of lived experiences and challenges of six secondary rural educators in Science Technology Engineering and Mathematics (STEM) fields. Through a focus interview, Goodpastor et al. noted the ways in which rural STEM educators described the benefits and complexities of teaching science education in high-poverty rural contexts. Moreover, these six educators also noted the many benefits of rural teaching in that there was the strong teacher-parent connection and mutual trust. These studies suggest the importance of examining the lived experiences of rural educators as a way to contextualize rural education beyond often times 'deficit' oriented perspectives.

This study provides an in-depth, year-long, exploration of ten rural educators' understandings of their visions, lived experiences and perspectives of teaching within rural contexts across elementary, middle and secondary school contexts. Moreover, it explores not only the challenges these educators face, but the ways in which these visions developed over time as a way to consider teacher visioning as a navigational tool for rural educators.

\section{Methods}

The research reported here used a phenomenological study to explore the development teacher visioning (Yin, 2009).In this way, the phenomenon of teacher visioning is examined through the voices of ten rural educators. In doing so, the purpose of this article is to fully conceptualize teacher visioning, agency and the supports needed to promote rural educators given the unique contexts of their particular schools. As such, the current study serves to "explore the meaning of individual experiences and how these meaning can be reduced to a description of the experiences" (Yin, 2009, p. 38).

\section{Context}

Participants were rural educators enrolled in a part-time Master's degree program designed to assist them in obtaining their degrees while remaining classroom teachers. Teachers participated in four semesters of coursework and spent six weeks on the university campus taking three intensive graduate 
level courses (Educational Philosophy, Theory, and Curriculum Development). The research team comprised of the professors on record for the courses taught within the Master's program (first and second author).

\section{Participants}

The ten volunteer participants were classroom teachers, within a Master's Degree Education program at a mid-sized public university in the
Pacific Northwest. Four participants were male and the other six were females; all were Caucasian. Five of the participants had been teaching between six and ten years. Five had been teaching between eleven and twenty years. All of the teachers worked in rural areas in Idaho and represented diverse subject areas and expertise. Three of the teachers taught in elementary school classrooms, one in special education, one in middle school, and five at the secondary level (See Table 1).

Table 1

Participants' Characteristics

\begin{tabular}{lll}
\hline Teacher & Years of Experience & Grade taught \\
\hline Anna & 9 & First grade \\
Jamie & 6 & First grade \\
Tia & 9 & Third grade \\
Connor & 8 & Sixth grade \\
Michael & 12 & H.S. Agriculture \\
John & 8 & H.S.Science \\
Maria & 18 & H.S. Foreign Language \\
Rachel & 4 & H.S. Business \\
Jace & 11 & H.S. Technology \\
Casey & 20 & Special Education \\
Jia & 8 & Sixth grade \\
\hline
\end{tabular}

\section{Data Collection}

To answer our research questions (What are the salient dimensions of teachers' reported visions across time and what are the challenges to enacting visions within rural contexts?) the researchers conducted interviews, focus group discussions, and collected a variety of student instructional artifacts (blogs, visual representations, reflective papers) to gain insight into participants' visions for teaching. Interviews were conducted by the researchers and occurred four times throughout the duration of the study and were guided by open ended questions to ascertain individual visions for teaching (What is your vision for teaching? Why? What are obstacles to enacting your vision you experience?). The first interview occurred during the first week of the first course in which the teachers participated. The second interview occurred during the fall semester. The third and final interview was conducted in the Spring and Summer semesters. Each interview was audiotaped and transcribed for analysis. Throughout the study, participants were asked to produce a reflective essay and blog entries regarding their understandings of their visions. In total, five blogs were used for data collection as way for the participants to have discussions with one another, and to provide reflection on course readings, their visions, and understandings of their work as teachers.

Focus groups with the participants were conducted four times during the length of the study. These discussions were audiotaped and transcribed for data analysis. These focus groups were guided by the question of (Can you tell me about your vision?) What followed were participants' responses about their vision and open discussion about what their visions meant to them. The researchers served as facilitators. Instructional artifacts (written responses in class, free writes) were also collected throughout the year to obtain additional insight about each participant's reported vision and the obstacles of which they reported.

\section{Data Analysis}

The research employed a grounded-theory approach (Strauss \& Corbin, 1998) as a systematic and exploratory research tool to provide detailed and rigorous procedures to generate understandings from the data. The first phase of the analysis involved open coding of the interviews and blog entries, which formed initial categories of information about the phenomenon of teacher visioning. These broad initial categories (the challenges of working as a teacher, elementary visions, middle and secondary school 
teachers' visions) led to an understanding of reported visions (Strauss \& Corbin, 1998).

In the second phase, we chose core categories (motivation, empowerment, life beyond school, skills oriented, obstacles of rural life, obstacles of elementary school and obstacles of teaching), that appeared in higher frequency across the data. Then, we developed, major categories (visions of self as teacher, visions of school, visions of students) and reviewed the themes. We examined the data through a constant comparative procedure, involving the comparison of data to the categories using the inductive process (from specific to broad). After this, a gradual refinement occurred with the analysis of blogs, focus groups, interviews and reflections from the participants. The overall intent of this process was to "ground" the categories in the data, to eliminate redundancy, and to develop evidence for the categories.

In the following paragraphs, teachers' visions and challenges are explored as a way to contextualize their respective experiences within their rural contexts. Such work is timely, as the nation continues to face emphasis on high-stakes assessments (See Race to the Top, 2009), the need to consider teachers' visions and experiences of teaching within rural communities as a way to further retain and support rural educators is imperative.

\section{Findings and Discussion}

Analysis of data revealed three broad themes related to teachers' visions for teaching: visions for self as teacher, students, and school. Interestingly, despite that teachers represented a wide range of grades and educational contexts, these broad categories were inclusive to each of the participants. Moreover, although teachers expressed challenges of enacting their visions given the specific nature their individual rural context presented, they appeared to show solidarity in their commitment to continue with meeting the needs of their students.

\section{Vision of Self}

At the beginning of the study, teachers were reluctant to view their roles as anything beyond just "a good teacher." During initial interviews when asked, "Tell me about you," they identified as that of a $1^{\text {st }}$ grade teacher or science teacher. For example, Jace stated, I am an elective teacher...I teach kids how to use technology (Jace interview, July 2011). However, as the study progressed, teachers began to self-identify as teacher researchers and leaders, often describing their identities beyond the role of classroom teachers. For example, Anna stated, As a classroom teacher and researcher my teaching is based on the experiences I work and reflect on as the type of teacher and researcher I strive to be...I want to become a catalyst for change (Anna interview, July 2011).

Similarly, Maria stated, We [teacher leaders] can change what is going on around us (Maria interview, August 2011). Rachel stated, I will be the person who opens the door, not the one who waits for it to be opened. (Rachel interview, August 2011).

Statements like this suggest that teachers began to broaden their understandings of their visions of self as "just good teachers" to that of teacher leaders and teacher researchers who had the capacity to implement systemic school wide change. Interestingly, although teachers expressed the challenges of working with others who did not appear to have the same passion to initiate change, they expressed the need to develop collaboration and to build knowledge with their colleagues. For example, Anna, further captured this idea:

I do have a vision to have the ability to be an integral part of the change that needs to happen in education. I believe that even though this is an impossible task for a single person, I do have the capability though my own practice, relationships and action research to inspire change that can really make a difference in my students and their learning and those people on my team and their students. (Anna interview, October 2011)

Across the data, participants expressed an emphasis on working to lead and to make changes at their rural schools. For example, participants like John thought deeply about the needs of their school community and expressed the need to change existing practices in order to achieve their vision. Noting that many of his junior and high school students were disengaged from seeing science as a possible career path, John began to work to build mentoring relationships between older and younger students in science. He initiated a school project where older students mentored younger students and taught hands on science lessons as a way to engage younger students. Through this experience, he noted, 'I've really seen how older students can really impact younger students and throughout that process, change the way that they think" (John artifact, December 2011).

These rural educators expressed visions of serving as role models for their students. For example, Connor captured this idea in his response, "I come from here. I want to be a role model. It is so important to get kids to know that school is important so they can go to college and live good lives." Interestingly, like Connor, all participants expressed 
a deep sense of responsibility to their students, and the need to initiate change as a way to promote students' learning opportunities beyond their current local communities. Such visions may serve to be powerful, motivational messages to rural students. As Goodpaster et al., (2012) found, rural educators' connections and commitments to their local communities are important factors in promoting student achievement.

However, for rural educators, this responsibility to provide a pathway for future opportunities is precarious. Unlike other larger urban school districts, due to budget cuts and teacher retention, rural schools like those in which these teachers taught that are small and located in remote, rural areas of the country, may be more likely to cancel courses and programs that are desperately needed for students' future success. In specific regards to this study, the five secondary rural educators taught within STEM fields and were the primary educators, who were responsible for teaching a multitude of subjects (Science Methods, Agriculture Education, Technology, Business Skills). Given the nation's emphasis on promoting STEM related fields (NCES, 2006) and the availability of STEM programs to support and recruit high school students to colleges and universities, access to future educational opportunities may be at risk if rural educators like those highlighted in this study leave their schools.

Despite this pressure, the rural educators within this study, expressed visions to lead their schools, and ultimately for developing instruction that would fit the individual and specific needs of their students. For example, Tia stated that she did not initially perceive herself as someone who implemented change but that she began to identify as a teacher leader by reflecting on her vision throughout the year. For example, her rural school district mandated the use of a prescriptive literacy program in order to meet the needs of her high-poverty rural students.

However, Tia stated that because her vision was to empower her students she needed to do literacy a different way. Testimonies like Tia's suggest that through examination of visions, teachers were able to enact change, serving as mediators between district, school mandates and their visions of effective instruction in order to meet the needs of their rural students. However, many teachers expressed an identity of a 'change agent' while simultaneously, expressed a sense of vulnerability about their work as teacher leaders. Jace seemed to capture the tension of working as a change agent while teaching within a small, rural community. The hardest thing is having to put your neck on the line all the time-that's where the courage factor comes in (Jace interview, August 2012). Indeed these educators were courageous in their work as visionary leaders despite the tensions and difficulties associated with the intersections of one's identity as 'visionary' and 'classroom teacher.'

\section{Vision for Students}

Interestingly, despite the wide grade span across the teachers, there appeared to be minimal differences in their visions for students. Overwhelmingly, the teachers emphasized the need to develop a 'life beyond school' perspective within their students, while emphasizing the need to develop academic and dispositional skills given the complex workforce their students would enter. For example, Rachel described her vision as working to prepare students for a life beyond school:

My vision is to prepare students for life after school, whether that be college or entering the workforce so to give them skills in the specific areas they need-and to more generally how to open something and figure things out. Know how to think through, analyze and problem solve.

(Rachel, interview, June 2012)

Others also echoed this dimension of fostering a 'life beyond school' perspective with their students. John expressed how he worked to structure his science classes so that his students could make connections from the classroom into their real life. In doing so, he emphasized that this could provide a way for his students to see other possibilities for their future: My vision is that I think they need to learn and to understand...Here's a concept how does it apply to you in your real life, can you use that or where will you use that in the future? (John interview, June 2012).

Other participants articulated visions for students where dispositional traits and academic skills were emphasized. Anna stated, I believe that kids should learn math concepts and communicate their thinking and to see themselves as mathematicians -so as to contribute positively to a larger community (Anna interview, April 2012). Further, she described her vision of promoting students who were productive, but also could develop dispositional skills she believed were important. She stated, I want kids to be able to interact with each other and see strengths of others. Similarly, Casey also expressed a vision for her students as responsible and of which would give to the greater community. My vision is that I want all my kids to be independent, compassionate, and productive members of society (Casey interview, June 2012). Shelly also expressed the need to develop collaborative students who possessed the necessary skills to be successful in life.

I would say that my goal is to develop wellrounded individuals... who are able to complete 
something, pull their experiences and knowledge and be able to be successful...to provide them with the skills that so they can use that for whatever they need in their future. (Shelly interview, June 2012)

Like Casey, Michael also expressed the need to develop skills that students could use in their lives after junior high and high school. For example, Michael focused on a vision that included an emphasis on lifelong skills:

Because I teach Agricultural Education, I truly believe that I need to develop students with lifelong skills that they will be able to use in a career, vocational training, or even around the house. The agricultural industry is all around us, everyone is affected by agriculture, believe it or not, but developing students' abilities to make informed decisions about global food, fiber, and natural systems is important. I want them to learn the skills that they can use in the work force or further education. (Michael artifact, December 2011)

Michael expressed the value of using the local environment as a way to build valuable skills and to further promote students' interests in future learning opportunities. Because rural settings may offer greater opportunities for learning of science and nature given students' familiarity with the outdoors (Avery \& Kassam, 2011), statements like Michael's offer insight into classroom practice and policy on pedagogical implications to incorporate nature, and the outdoors to engage rural student populations. Moreover, although rural educators face increasing pressures to increase student performance on highstakes assessments, as the nation faces increased emphasis on national standards and increased pay for performance measures (See Race to the Top, 2009), experiences like that of Michael point to continued understanding and research into ways to incorporate the natural environment into rural education despite today's high-stakes accountability context.

Teachers also emphasized the necessity to focus on dispositional skills such as character building and social responsibility. Maria shared, Building of character of the individual is the heart and soul of this educational process. She explained her vision as that of building character of individuals through:

My vision is to promote students how have

kindness, care, compassion, fairness and respect [which] is engrained in the moral development of the human being. As the learners understand the connection of humanity within the classroom, they will assume a social responsibility into adulthood. (Maria interview, April 2011)

Like Maria, such thoughtful responses highlighted a sense of community building within her closely knit school and the local rural community. Rural schools like that of which Maria taught are situated within small communities where teachers often see their students beyond school hours. As a result, rural educators like Maria, have in-depth knowledge of their students' families, interests, and challenges of living within a rural community.

Throughout the study, teachers' visions for students remained consistent. That is, teachers' reported visions that focused on developing dispositional skills in their students (productive, respectful, and independent) while emphasizing visions of fostering 'a life beyond school' perspective. Moreover, visions were anchored in developing academic skills that would allow for success within school and beyond their current school lives. Although extant literature emphasizes the rationales as to why rural educators leave the profession (Huysman, 2009) and the negative dimensions associated with teaching in rural schools (Wenger et al., 2012) these testimonies of rural educators' visions to lead school wide change offer promising insight into pedagogical implications of policy for rural school districts.

\section{Vision for School}

Many of the teachers expressed an emphasis on respect, trust, and collaboration as salient dimensions of their visions for their schools. For example, Jace shared his vision for his school. I see collaboration as very important piece at the district level, when teachers from many different disciplines and grades levels have to find common ground for students (Jace interview, August 2011).

Similarly, Jamie also expressed a vision of a school that embraced relationship building and collaboration as a way to promote student learning and communication. She stated, I have learned [that my school] must develop and build relationships within our school system just in order to function (Jamie focus group, December 2011). Indeed, support and collaboration among teachers is a vision that many teachers express as an essential component to teacher retention (Vaughn, 2013) however for rural educators, with limited numbers of faculty, and scarce resources, the challenges to cultivate collaborative relationships is essential to support day to day functioning and student success. Further, John expressed that although he taught in a small, rural community, with its disadvantages of limited resources, such a close community provided what he believed was an untapped potential. Junior high and high school teachers could collaborate and form $a$ tight and protective bond with their students. 
However, because of their close and often-times geographically smaller communities, these rural educators also reported a sense of fragility in their visions for their schools, given the unique and small communities of which they taught. For example, Anna explained, At this point, my vision seems inconsistent with the direction that my building seems to be going. I find that I have to 'fly under the radar' to do things the way I want to do them (Anna interview, August 2012). In flying under the radar, Anna tried different instructional approaches she believed met the individual and specific needs of their students, but were in conflict with their school administration or colleague's vision for the school. Overwhelmingly, teachers expressed an emphasis on a vision for a school where there was respect, trust, and collaboration as evidenced in their statements.

\section{Obstacles to Enacting One's Vision}

Enacting their visions appeared to be teachers' primary obstacles. For example, Michael expressed the challenges of teaching within a school system where many of his students could not see a vision of their future self as one of his primary obstacles. He stated, I struggle to get them [students] to understand that yes it's [a future in science] is just out there and there are applications. Similarly, John expressed the difficulty of engaging students and the obstacles his students faced that hindered their ability to engage in science and to see science as a part of their future. He reasoned, Maybe they [students] have other problems at home or other issues that they're facing. Perhaps it's just the kids that I have. Statements like these express the difficulty these rural educators faced when working to enact their visions.

Other challenges included a lack of materials, building mandates, and an overall lack of administrator support. For example, Rachel seemed to summarize the frustration of teaching within a rural school where she often lacked the necessary resources to effectively teach:

Well, at my school even if you may have the funding for getting the computers, you may not have the funding to buy new textbooks that go along with that or the training. It especially hits with textbooks and computers... so a lot of times you are teaching with older books with a newer program or you are teaching an older program that the kids might not use the next year. (Rachel interview, August 2012)

John shared the difficulty of working as the primary content area teacher, who was responsible for teaching a multitude of grades. Because of the limited faculty, his colleagues were asked to handle additional responsibilities (test prep, afterschool responsibilities, and remedial tutoring.

There are some obstacles like, working in the school that I work in being a small rural school. There are a lot of different classes to prep for. And I don't always feel like I have enough time, I mean just 24 hours in a day is hard sometimes to get six different science preps in. I guess that's something you just kind of sign up for when you are a small school teacher. (John interview, August 2012)

Overall, teachers reported the lack of funding to support student learning (i.e., computers, textbooks, faculty, and professional development) as their primary obstacle to practicing according to their visions. Other obstacles to practicing according to visions included the difficulty of school leadership and the challenges of teaching within rural contexts. Research suggests that such challenges often influence teacher attrition and retention in rural contexts (Huysman, 2009).

Despite these challenges, teachers expressed a sense of responsibility in working to enact practices according to their visions given their close ties to their respective rural communities. Given that all of the teachers were raised either in the rural communities in which they taught $(\mathrm{n}=8)$ or had lived in that rural community for more than five years $(n=2)$, they expressed deep feelings and connections to their students, school, and community as evidenced in their rationales for negotiating obstacles in order to teach according to their visions. As such, these rural educators faced these challenges and adopted the role of change agent to implement school-wide changes.

The current study examined the visions of ten rural educators from a variety of grade levels, over the course of one academic year, given the challenges they experienced in their rural settings. Visions were multidimensional in nature reflecting visions of self, visions for students, and visions for schools. Of interest to administration, is that among the participants there appeared to be a deep sense of responsibility and commitment to providing access to future educational opportunities for their students, and to promote visions for their students to see a 'life beyond' school. Despite the challenging contexts of which these rural educators faced, they expressed a sense of resiliency, commitment and responsibility to their students, schools and rural communities.

The obstacles posed by these rural educators, are similar to the challenges documented of teaching within rural contexts (See Goodpastor et al., 2009). However, unlike Jazabkowski (2003), who suggested that teachers in rural contexts because of their closeknit community often-times teach in collegial settings 
where they are allowed to take risks, the current study found that the work of visionary leaders can be complex. The findings of this study causes the need to consider to the extent to which rural educators feel isolated as they embrace the work of visionary leaders and change agents. Like many teachers, these rural educators worked as 'back seat' change agents and often experienced difficulties as they worked to enact their visions. Moreover, such findings highlight the complexity that may occur as 'visionary leaders' enter and teach in small rural school communities.

However, findings offer valuable information for teacher educators who work with developing preservice educators, particularly in those colleges and universities across the country who are in close proximity to rural, high poverty school districts. Implications for rural teacher preparation may include encouraging prospective teachers to develop their visions, cognizant of the benefits of rural communities, with knowledge of effective pedagogy to meet the specific and individual needs of rural students. Findings suggest that teacher visioning may serve as a tool to encourage and to foster individuality and academic creativity. Finally, school administration may be encouraged by these rural educators' testimonies and their sense of responsibility, courage, and resiliency to do what they believed worked best for their individual students and greater communities.

\section{Conclusion}

This study examined teacher visioning and the lived experiences of ten rural educators and has potential to offer insight into teacher visioning as a navigational tool for rural educators.

Findings highlighted the ways in which teachers developed their visions to foster change within their schools and to what they ultimately believed worked best for their students. As rural school districts continue to face post NCLB (2001) pressures to deliver standards based curriculum, the voices of rural educators and the school context of which these teachers face provides important and compelling insight. Although there is literature highlighting the challenges rural teachers, rarely do we hear of rural teacher leaders who have visions of what could be like the ones presented here. Moreover, as the nation continues to face continued emphasis on high-stakes assessments (See Race to the Top, 2009), it becomes even more imperative to take into account teachers' visions for teaching and the diversity of individual rural communities as a way to further retain and support rural educators.

A limitation of this study is the small sample size consisting of ten rural teachers from the Pacific Northwest. Teachers within this program were considered unique in that they sought to enter into a graduate program while remaining in the classroom. Therefore, the findings may differ with other rural populations. Consequently, results cannot be generalized beyond that of the scope of the current study. Future research may use additional qualitative measures (reflective journals and additional interviews) to examine more fully the development of visions over time and the enactment of one's vision despite perceived constraints.

\section{References}

Avery, L.M., \& Kassam, K.A. (2011). Phronesis: Children's local rural knowledge of science and engineering. Journal of Research in Rural Education, 26 (2).

Azano, A. (2011). The Possibility of Place: One Teacher's Use of Place-Based Instruction for English Students in a Rural High School. Journal of Research in Rural Education, 26(10).

Bates, V. (2011). Preparing rural music teachers: Reflecting on "shared visions." Journal of Music Teacher Education, 20(2), 89-98.

Burton, M., \& Johnson, A. S. (2010). "Where else would we teach?" Portraits of two teachers in the rural South. Journal of Teacher Education, 61(4), 376-386.

Creswell, J. W. (2008). Educational research. Planning, conducting, and evaluating quantitative and qualitative research (3rd ed.).Columbus, $\mathrm{OH}$ : Merrill Prentice-Hall.

Duffy, G. G. (2002). Visioning and the development of outstanding teachers. Reading Research and Instruction, 41, 331-344.

Goodpastor, K., Adedokun, O., \& Weaver, G. (2012) Teachers' perceptions of rural STEM teaching: Implications for rural teacher retention. Rural Educator, 33(3), 8-22.

Hammerness, K. (2006). Seeing through teachers' eyes: Professional ideals and classroom practices. New York: Teachers College Press.

Hammerness, K. (2008). "If you don't know where you are going, any path will do": The role of teachers' visions in teachers' career paths. New Educator, 4, 1-22. 
Huysman, J. T. (2009). Rural teacher satisfaction: An analysis of beliefs and attitudes of rural teachers' job satisfaction. Rural Educator, 29(2), 31-38.

Johnson, J., \& Strange, M. (2007). Why rural matters 2007: The realities of rural education growth. Arlington, VA: Rural School and Community Trust.

Jarzabkowski, L. (2003). Teacher collegiality in a remote Australian school. Journal of Research in Rural Education, 18(3), 139-144.

Mertler, C. A. (2012). Action research: Improving schools and empowering educators. Thousand Oaks, CA: Sage.

Monk, D. H. (2007). Recruiting and retaining highquality teachers in rural areas. The Future of Children, 17, 155-174.

National Center for Education. (2010). Reading 2009: National assessment of educational progress at grades 4 and 8. Washington, D.C.: National Center for Education Statistics, Institute of Education Sciences, U.S. Dept. of Education.

No Child Left Behind Act of 2001. (2002). (PL 107110). Retrieved from http://www.ed.gov/policy/elsec/leg/esea02/index .html

Race to the Top (H.R. 1532--112th Congress: Race to the Top Act of 2011). (2009). Retrieved November 27,2012, from http://www.govtrack.us/congress/bills/112/hr153 2

Paris, C., \& Lung, P. (2008). Agency and childcentered practices in novice teachers: Autonomy, efficacy, intentionality, and reflectivity. Journal of Early Childhood Teacher Education, 29(3), 253-268.

Powell, D., Higgins, H. J., Aram, R., \& Freed, A. (2009). Impact of No Child Left Behind on curriculum and instruction in rural schools. Rural Educator, 31(1), 19-28.
Sloan, K.. (2006).Teacher identity and agency in school worlds: Beyond the all-good/all-bad discourse on accountability explicit curriculum policies. Curriculum Inquiry, 36(2), 119-152.

Spradley, J. P. (1979). The ethnographic interview. Belmont, CA: Wadsworth, Cengage Learning.

Strauss, A., \& Corbin, J. (1998). Basics of qualitative research. Techniques and procedures for developing grounded theory ( $2 \mathrm{nd}$ ed.). Thousand Oaks, CA: Sage.

Tracey, D. H., \& Morrow, L. M. (2012). Lenses on reading: An introduction to theories and models $\left(2^{\text {nd }}\right.$ ed.). New York: Guilford.

Vaughn, M. (2013). Examining teacher agency: Why did Les leave the building? New Educator 9(2), 119-134.

Vaughn, M., \& Faircloth, B. (2011). Understanding teacher visioning and agency during literacy instruction. In In J. V. Hoffman, D. Shallert, C. Fairbanks, J. Worthy, \& B. Maloch (Eds.), $60^{\text {th }}$ Yearbook of the Literacy Research Association (pp. 309-323). Oak Creek, WI: National Reading Conference.

Vaughn, M. \& Parsons,S.A. (2012). Visions, enactments, obstacles and negotiations: Case studies of two novice teachers enrolled in a graduate literacy course. Journal of Reading Education. 38(1), 18-25.

Vygotsky, L. S. (1978). Mind in society: The development of higher psychological processes. Cambridge, MA: Harvard University Press.

Wenger, K.J., Dinsmore, J., \& Villagomez, A. (2012). Teacher identity in a multicultural rural school: Lessons learned at Vista Charter. Journal of Research in Rural Education, 27(5), 1-17.

Yin, R. K. (2009). Case study research: Design and methods. Los Angeles, CA: Sage.

\section{About the Authors:}

Margaret Vaughn is an assistant professor in Curriculum and Instruction at the University of Idaho. She teaches undergraduate and graduate courses centered on literacy and research methodologies. Her research interests include adaptive teaching, issues of agency and literacy instruction. She works with pre-service and in-service teachers to explore and generate ideas and practices meaningful to literacy instruction. mvaughn@uidaho.edu

Melissa Saul is an Educational Specialist with a dual appointment in the Division of Education and Office of Sustainability at University of Hawaii @ West Oahu. Her teaching has focused on social justice and global education within teacher education. Her research interests include issues of education and citizenship in a global society, culturally responsive pedagogy and place-based education. 